\title{
CONTROLE JUDICIAL DA DISCRICIONARIEDADE ADMINISTRATIVA, COM ENFOQUE NA JURISPRUDÊNCIA DO SUPREMO TRIBUNAL FEDERAL E DO SUPERIOR TRIBUNAL DE JUSTIÇA
}

Tiago Fuchs Marino ${ }^{1}$ Noemi Mendes Siqueira Ferrigolo²

MARINO, T. F.; FERRIGOLO, N. M. S. Controle judicial da discricionariedade administrativa, com enfoque na jurisprudência do supremo tribunal federal e do superior tribunal de justiça. Rev. Ciênc. Juríd. Soc. UNIPAR. Umuarama. v. 19, n. 1, p. 87-114, jan./jun. 2016.

RESUMO: O presente artigo tem por escopo demonstrar a possibilidade de controle jurisdicional da discricionariedade administrativa, sob o prisma da Constituição Federal. Durante muito tempo, a doutrina e a jurisprudência sustentaram que a interveniência do Poder Judiciário sobre os atos discricionários deveria se restringir aos aspectos de legalidade, sem adentrar ao exame do mérito administrativo. Entretanto, modernamente foram criadas teorias, aplicadas em alguns casos pelo Supremo Tribunal Federal e pelo Superior Tribunal de Justiça, que limitam a discricionariedade administrativa e ampliam as hipóteses de controle judicial, de maneira a evitar arbitrariedades estatais e satisfazer os interesses da coletividade.

PALAVRAS-CHAVES: Administração Pública; Ato administrativo; Controle jurisdicional; Discricionariedade administrativa; Superior Tribunal de Justiça; Supremo Tribunal Federal.

\section{INTRODUÇÃO}

Nos últimos anos ganharam destaque as controvérsias judiciais envolvendo os atos praticados pela Administração Pública, que fizeram ressurgir antigas reflexões na doutrina e na jurisprudência sobre a possibilidade e limites do controle judicial de tais atos, notadamente daqueles classificados como discricionários, decorrentes de um juízo de conveniência e oportunidade emitido pelo administrador.

O controle judicial, diante do princípio da inafastabilidade da jurisdi-

${ }^{1}$ Acadêmico de Direito do Centro Universitário da Grande Dourados - UNIGRAN. Estagiário no Ministério Público Federal. Email: tiagomarino@icloud.com.

${ }^{2}$ Graduada em Relações Públicas pela Universidade Federal de Santa Maria. Bacharel em Direito pelo Centro Universitário da Grande Dourados - UNIGRAN. Mestre em Direito pela Universidade de Brasília. Professora no Centro Universitário da Grande Dourados - UNIGRAN. 
ção, constitui um dos ideais do Estado Democrático de Direito. Afinal, de nada adiantaria a elaboração de leis que regulassem a Administração Pública, visando à satisfação do interesse público e a coibição de arbitrariedades, se não houvesse um órgão, independente e dotado de imparcialidade, capaz de proceder a um controle sobre os atos ilegais praticados por ela.

Questiona-se, entretanto, se tal controle não violaria o princípio da independência dos poderes estampado em nossa Constituição da República; e, ainda que não o fizesse, se deveria se restringir aos aspectos da legalidade.

Diante disso, o presente trabalho buscará, por meio de levantamento doutrinário e, especialmente, de pesquisa realizada na jurisprudência do Supremo Tribunal Federal e do Superior Tribunal de Justiça, verificar a possibilidade de interveniência do Poder Judiciário sobre os atos administrativos discricionários, determinando o limite de seu alcance.

\section{Breves considerações sobre a Separação dos Poderes}

Na busca pelo bem-estar social, o Estado desempenha suas atividades através dos chamados "três poderes", os quais, consoante a teoria de Montesquieu, são: o Legislativo, o Executivo e o Judiciário.

A Constituição da República de 1988 prevê, em seu artigo $2^{\circ}$, que tais poderes são independentes e harmônicos entre si. E mais, nos termos do seu artigo $60, \S 4^{\circ}$, inciso III, a separação dos poderes é cláusula pétrea, ou seja, não pode ser objeto de eventual proposta de emenda constitucional.

Acerca do tema, leciona Moraes (2006. p. 383):

A Constituição Federal, visando, principalmente, evitar o arbítrio e o desrespeito aos direitos fundamentais do homem, previu a existência dos Poderes do Estado e da Instituição do Ministério Público, independentes e harmônicos entre si, repartindo entre eles as funções estatais e prevendo prerrogativas e imunidades para que bem pudessem exercê-las, bem como criando mecanismos de controles recíprocos, sempre como garantia da perpetuidade do Estado Democrático de Direito.

O legislador constituinte atribuiu a cada um dos poderes uma função típica, a saber: ao Legislativo, conferiu a função de elaborar leis (função normativa); ao Executivo, a função de promover a execução das leis, diante de casos concretos (função administrativa); e ao Judiciário, a função de aplicar a lei coercitivamente, depois de provocado (função jurisdicional).

A ideia da tripartição tem por objetivo impedir a concentração de poderes e, assim, preservar a liberdade dos homens em face de atitudes arbitrárias 
e abusivas dos governantes. Daí se extrai o princípio da separação dos poderes. Ressalva Meirelles (2014, p. 63) que:

Embora o ideal fosse a privatividade de cada função para cada Poder, na realidade isso não ocorre, uma vez que todos os Poderes têm necessidade de praticar atos administrativos, ainda que restritos à sua organização e ao seu funcionamento, e, em caráter excepcional admitido pela Constituição, desempenham funções e praticam atos que, a rigor, seriam de outro Poder. O que há, portanto, não é separação de Poderes com divisão absoluta de funções, mas, sim,distribuição das três funções estatais precípuas entre órgãos independentes, mas harmônicos e coordenados no seu funcionamento, mesmo porque o poder estatal é uno e indivisível.

Nesse diapasão, a doutrina majoritária vem insistindo que a separação dos poderes não pode ser analisada de maneira absoluta. Na verdade, muitos autores preferem falar em "separação de funções".

É que o poder de soberania, como se sabe, é uno e indivisível. Não se pode cogitar, portanto, a coexistência de duas ou mais soberanias dentro de um mesmo Estado, porém é perfeitamente possível admitir uma pluralidade de órgãos de manifestação do poder soberano - isto é, cada órgão exercendo a totalidade do poder soberano, dentro de sua competência (MALUF, 2013, p. 219).

Saliente-se que a distribuição das funções entre os respectivos órgãos não se dá de maneira absoluta e exclusiva. Confere-se a cada um determinada função típica, mas também, excepcionalmente, a possibilidade de praticar atos e funções que, a rigor, competem a outro poder (função atípica). Essa solução normativa, denominada de mecanismo de "freios e contrapesos" (checks and balances), visa a efetivar um equilíbrio entre os órgãos autônomos, de modo que um "poder" limite o outro (MELLO, 2014, p. 32).

Sendo assim, por exemplo, o Legislativo deve, primordialmente, legislar, porém, como exceção, julga os crimes de responsabilidade do Presidente da República. O Judiciário, cuja função típica é julgar, atipicamente elabora seu regimento interno e suas propostas orçamentárias. E o Executivo, incumbido da administração da coisa pública, pode editar medida provisória, em caso de relevância e urgência.

\section{A Administração Pública e os Atos Administrativos}

\subsection{Conceito de Administração Pública}

São duas as acepções utilizadas na doutrina, frequentemente, para o 
emprego do vocábulo Administração Pública: a) em sentido subjetivo, consiste nas pessoas jurídicas, órgãos e agentes públicos incumbidos de exercer a já mencionada função estatal administrativa; e, b) em sentido objetivo, designa a natureza da atividade exercida pelos referidos entes, tratando-se, portanto, da própria função administrativa que, como já visto, é exercida predominantemente pelo Poder Executivo.

Em síntese, ensina Moraes (2006, p. 302):

A administração pública pode ser definida objetivamente como a atividade concreta e imediata que o Estado desenvolve para a consecução dos interesses coletivos e subjetivamente como o conjunto de órgãos e de pessoas jurídicas aos quais a lei atribui o exercício da função administrativa do Estado.

Os serviços públicos são prestados predominantemente pela Administração Pública, de forma direta (ou seja, por seus órgãos e entidades) ou de forma indireta - caso em que ela delega tais serviços a outras pessoas jurídicas (ARAÚJO, 2009, p. 127).

Nesse sentido, a Administração Pública tem natureza de um múnus público para quem a exerce, ou seja, a de um dever de defender, conservar e aprimorar bens, serviços e interesses da coletividade. Incumbe-se ao administrador público a obrigação de observar fielmente o Direito e a moral administrativa que regulamentam sua atuação. É que, ao ser investido em função ou cargo público, o agente automaticamente assume com o povo - legítimo destinatário dos serviços administrados pelo Estado - o compromisso de servi-lo bem (MEIRELLES, 2014, p. 88).

Por conseguinte, os fins da Administração Pública são aqueles que representam o interesse público. Necessário citar Mello (2014, p. 59):

Ao se pensar em interesse público, pensa-se, habitualmente, em uma categoria contraposta a de interesse privado, individual, isto é, ao interesse pessoal de cada um. Acerta-se em dizer que se constitui no interesse do todo, ou seja, do próprio conjunto social, assim como acerta-se também em sublinhar que não se confunde com a somatória dos interesses individuais, peculiares de cada qual [...] É que, na verdade, o interesse público, o interesse do todo, do conjunto social, nada mais é que a dimensão pública dos interesses individuais, ou seja, dos interesses de cada indivíduo enquanto partícipe da Sociedade (entificada juridicamente no Estado), nisto se abrigando também o depósito intertemporal destes mesmos interesses, vale dizer, já agora encarados eles em sua continuidade histórica, tendo em vista a sucessividade das gerações de seus nacionais. 
Ao agir pautando-se por outro objetivo que não esse (como, e.g., seu interesse pessoal), o gestor da coisa pública trai a confiança de seus administrados, agindo em desvio de poder.

\subsection{Definição de Ato Administrativo}

No exercício de sua função, a Administração Pública realiza atos jurídicos que recebem a denominação de atos administrativos. Tais atos, por sua natureza, conteúdo e forma, se diferem daqueles emanados da função normativa (leis) e da função jurisdicional (decisões proferidas por magistrados) (MEIRELLES, 2014, p. 162).

Por óbvio, a prática de tais atos cabe, via de regra, aos órgãos do Poder Executivo. Não obstante, as autoridades judiciárias e legislativas também os praticam, de maneira excepcional, quando ordenam seus próprios serviços, dispõem sobre seus servidores ou expedem instruções sobre matéria de sua competência privativa, de modo que estarão igualmente sujeitos à revogação ou anulação no âmbito interno ou pelas vias judiciais, tal como ocorre com os atos emanados pelos órgãos executivos - o que será abordado mais adiante (MEIRELLES, 2014, p. 163).

Mello (2014, p. 389) conceitua o ato administrativo como:

Declaração do Estado (ou de quem lhe faça as vezes - como, por exemplo, um concessionário de serviço público), no exercício de prerrogativas públicas, manifestada mediante providências jurídicas complementares da lei a título de lhe dar cumprimento, e sujeitas a controle de legitimidade por órgão jurisdicional.

Trata-se, assim, de manifestação unilateral de vontade da Administração, o que se deve aos interesses por ela representados que lhe permitem impor o cumprimento de obrigações, mesmo que nenhuma ilegalidade tenha sido praticada pelos administrados (SPLITZCOVSKY, 2013, p. 129-130).

Importante ressaltar que a referida manifestação de vontade pode, também, provir de terceiros que, investidos em prerrogativas estatais, prestam serviços públicos, como as empresas concessionárias e permissionárias.

Para se diferenciar devidamente o ato administrativo dos atos jurídicos de direito privado, torna-se imperioso tratar de seus atributos, a saber: a) presunção de legitimidade e veracidade; b) imperatividade; c) autoexecutoriedade; e d) tipicidade.

É sabido que os atos administrativos, desde seu surgimento, carregam com si a presunção de legitimidade e veracidade, independentemente de lei que trate do assunto. Tal presunção decorre do próprio princípio da legalidade, con- 
sagrado no artigo 37, caput, da Constituição Federal de 1988.

Oportuno distinguir a presunção de legitimidade da presunção de veracidade. A primeira diz respeito à conformidade do ato com a lei, isto é, sempre se presume, até prova em contrário, que o ato administrativo foi emitido em observância à lei. Já a segunda corresponde aos fatos: como consequência desse atributo, presumem-se verdadeiros quaisquer fatos alegados pela Administração (certidões, atestados, declarações, informações e demais documentos, todos dotados de fé pública), havendo transferência do ônus da prova de invalidade do ato administrativo para quem a invoca (DI PIETRO, 2014, p. 206-207).

A imperatividade refere-se à capacidade de os atos administrativos se imporem, de per si, sobre os administrados, sendo irrelevante a anuência destes. Tal atributo permite fazer uma diferenciação clara dos atos de direito privado, em que somente é criada obrigação para terceiro com sua concordância.

A autoexecutoriedade consiste na possibilidade que alguns atos administrativos sejam de imediata e direta execução pela própria Administração, independentemente de ordem judicial (MEIRELLES, 2014, p. 177).

Por fim, tem-se a tipicidade, atributo pelo qual o ato administrativo deve corresponder a figuras definidas previamente pela lei como aptas a produzir determinados resultados. Significa dizer que, para cada finalidade que a Administração pretende alcançar, existe um ato definido em lei.

Também este último atributo decorre do princípio da legalidade, que veda à Administração praticar atos sem lei que a autorize ou determine (inominados). Consiste em verdadeira proteção ao administrado contra eventuais atos do Poder Público que o vinculem unilateralmente sem previsão legal.

\subsection{Requisitos de Validade do Ato Administrativo}

Os atos administrativos, como modalidade de ato jurídico, não dispensam os três requisitos de validade previstos no artigo 104 do Código Civil de 2002, quais sejam: agente capaz, objeto lícito, possível, determinado ou determinável e forma prescrita ou não defesa em lei. Não obstante, sofrem algumas adaptações decorrentes dos diferentes interesses tutelados (SPLITZCOVSKY, 2013, p. 131).

Não obstante, diante da prevalência do interesse público, eles exigem outros requisitos que vão além daqueles necessários à prática de atos jurídicos privados.

O primeiro requisito a ser analisado, que garante validade ao ato administrativo, é a competência, que, no magistério de Meirelles (2014, p. 167), é “o poder atribuído ao agente da Administração para o desempenho específico de suas funções". 
A competência deriva da lei e por ela sofre limitações. Trata-se de poder intransferível e improrrogável, sendo passível de delegação ou avocação somente nas hipóteses autorizadas pelas normas que regulam o ente administrativo que venha a praticar o ato.

Em segundo lugar, tem-se a finalidade, que deve ser aquela que a lei indica explícita ou implicitamente, não cabendo ao gestor da coisa pública escolher outra, sob pena de restar caracterizado desvio de poder e, consequentemente, ensejar a invalidação do ato. Todo ato proveniente das pessoas jurídicas e órgãos da Administração, vale dizer, devem se pautar em um objetivo proposto na lei que executam.

Como terceiro requisito, vem a forma, isto é, o revestimento exteriorizador do ato administrativo. É que, diferentemente do que ocorre entre os particulares, a manifestação de vontade da Administração exige procedimentos especiais e forma legal para que se expresse validamente. Assim, no Direito Privado tem-se a liberdade da forma como regra; no Direito Público, é a exceção (MEIRELLES, 2014, p. 168).

Justifica-se tal exigência diante da eventualidade de o ato ser impugnado, pela própria Administração ou mesmo por órgão do Poder Judiciário, em aferição de sua (in)validade.

Em que pese tais ponderações, Di Pietro (2014, p. 217) explica:

A obediência à forma não significa, no entanto, que a Administração esteja sujeita a formas rígidas e sacramentais; o que se exige, a rigor, é que seja adotada, como regra, a forma escrita, para que tudo fique documentado e passível de verificação a todo momento; a não ser que a lei preveja expressamente determinada forma (como decreto, resolução, portaria, etc.), a Administração pode praticar o ato pela forma que the parecer mais adequada. Normalmente, as formas mais rigorosas são exigidas quando estejam em jogo direitos dos administrados, como ocorre nos concursos públicos, na licitação, no processo disciplinar.

Ainda, deve o ato administrativo respeitar o requisito do motivo. Este consiste na situação de direito ou de fato que determina ou autoriza a realização do ato. O motivo, como elemento integrante da perfeição do ato, pode vir expresso em lei (vinculado) ou ser deixado a critério do administrador (discricionário) (MEIRELLES, 2014, p. 171). A diferenciação das duas situações será feita em tópico próprio, posto que de extrema relevância ao presente trabalho.

A exposição do motivo objetiva proteger os cidadãos de abusos do Estado e caprichos dos governantes. Desse modo, devem ser expostos, de maneira convincente, os motivos que ensejaram a prática do ato, inclusive para assegurar 
a eventuais lesados o direito ao contraditório e à ampla defesa.

Pegoraro (2010, p. 47) enfatiza que:

Os motivos alegados para a prática de um ato ficam a ele vinculados de tal forma, que, se um ato administrativo for praticado diante da alegação de motivo falso ou inexistente, será tido como inválido. Funda-se na consideração de que os atos administrativos, quando tiverem sua prática motivada, ficam vinculados aos motivos expostos, para todos os efeitos jurídicos. Deve haver perfeita correspondência entre eles e a realidade.

Por fim, também há que se considerar o objeto ou conteúdo, que é o efeito jurídico imediato que o ato produz.

Tendo em vista que o Código Civil de 2002 exige, conforme referido alhures, objeto lícito como requisito de validade dos atos emitidos por particulares, com muito maior razão essa condição recai sobre os atos administrativos, cujos efeitos repercutem sobre a coletividade. É de se consignar, porque importante, que enquanto a licitude dos atos praticados pelos particulares caracteriza-se pela não contrariedade à lei, a dos atos administrativos verifica-se pela compatibilidade em relação a ela (SPLITZCOVSKY, 2013, p. 132).

Por conseguinte, o objeto também deve ser certo (definido quanto ao destinatário, aos efeitos, ao tempo e ao lugar) e moral (em conformidade com os padrões comuns de comportamento, aceitos como corretos, éticos e justos) (DI PIETRO, 2014, p. 216).

\section{Discricionariedade Administrativa}

Para Mello (2014, p. 434), "uma das grandes distinções que se faz entre os atos administrativos e à qual se atribui o maior relevo, com justa razão, é a que os separa em atos vinculados e discricionários". Não são poucas as situações, no exercício da atividade administrativa corriqueira, que exigem conhecimento sobre a o tema. Isto posto, torna-se fundamental fazer uma abordagem ampla sobre a diferenciação das duas modalidades de atos.

Atos vinculados são aqueles para os quais a lei estabelece os requisitos e condições de sua realização, absorvendo quase totalmente a liberdade do administrador, uma vez que sua ação fica adstrita aos pressupostos legais. Diante da inobservância de qualquer desses pressupostos, compromete-se a eficácia do ato praticado (MEIRELLES, 2014, p. 183).

Previne Meirelles (2014, p. 164):

Isso não significa que nessa categoria de atos o administrador se 
converte em cego e automático executor da lei. Absolutamente, não. Tanto nos atos vinculados como nos que resultam da faculdade discricionário do Poder Público o administrador terá de decidir sobre a conveniência de sua prática, escolhendo a melhor oportunidade e atendendo a todas as circunstâncias que conduzam a atividade administrativa ao seu verdadeiro e único objetivo - o bem comum. Poderá, assim, a Administração Pública atuar com liberdade, embora reduzida, nos claros da lei ou do regulamento. O que não the é licito é desatender as imposições legais ou regulamentares que regram o ato e bitolam sua prática.

De outro giro, consideram-se atos discricionários aqueles que a Administração pode praticar, autorizada pela lei, com liberdade de escolha de seu conteúdo, de seu destinatário, de sua conveniência, de sua oportunidade e do modo de sua realização (MEIRELLES, 2014, p. 164).

Em síntese, são atos em que o administrador faz um juízo subjetivo de conveniência e oportunidade sobre a prática do ato e todas as suas nuances.

Conclui Mello (2007, p. 9):

É clássica a distinção entre atos expedidos no exercício de competência vinculado e atos praticados no desempenho de competência discricionária. Sobre este tema já se verteram rios de tinta. Haveria atuação vinculada $\mathrm{e}$, portanto, um poder vinculado, quando a norma a ser cumprida já predetermina e de modo completo qual o único comportamento que o administrador estará obrigado a tomar perante casos concretos esteja descrita, pela lei, em termos que não ensejam dúvida alguma quanto ao seu objetivo reconhecimento. Opostamente, haveria atuação discricionária quando, em decorrência do modo pelo qual o Direito regulou a atuação administrativa, resulta para o administrador um campo de liberdade em cujo interior cabe interferência de uma apreciação subjetiva sua quanto à maneira de proceder nos casos concretos, assistindo-lhe, então, sobre eles prover na conformidade de uma intelecção, cujo acerto seja irredutível à objetividade e ou segundo critérios de conveniência e oportunidade administrativa.

Observa-se, portanto, que tanto os atos vinculados como os discricionários são realizados em observância às normas legais; o que lhes difere, entretanto, é a extensão da liberdade conferida ao administrador, quanto à prática (ou não) de determinado ato ou mesmo sobre a forma como este será praticado.

A discricionariedade administrativa justifica-se na complexidade das situações e obstáculos que a Administração Pública precisa superar na persecução do bem-estar social e para os quais o legislador, por mais delimitativo e específico que fosse, não poderia prever todas as soluções ou, pelo menos, a mais 
vantajosa ao caso concreto (MEIRELLES, 2014, p. 185).

Ensina Di Pietro (2014, p. 221) que a doutrina clássica aponta a existência de um critério jurídico e um prático para sustentar a existência da discricionariedade.

O primeiro utiliza-se da teoria da formação do Direito por degraus, de Kelsen: tendo em vista os graus pelos quais se expressa o Direito, a cada ato acrescenta-se um elemento novo não previsto no anterior; esse acréscimo se faz com o uso da discricionariedade, existente, portanto, para tornar possível a existência dos acréscimos.

No campo prático, a discricionariedade justifica-se para evitar o automatismo decorrente da aplicação rigorosa de regras preestabelecidas; e, também, diante da impossibilidade de a lei prever todas as situações possíveis que o Poder Público deve enfrentar. Nos dois casos, deve se considerar que a discricionariedade é fundamental para viabilizar o poder de iniciativa da Administração para atender às infinitas necessidades coletivas (DI PIETRO, 2014, p. 221).

Mello leciona que é raro a lei estabelecer, com precisão, qual a situação de fato objetivamente identificável e qual a conduta única e perfeita a ser adotada pela Administração Pública perante tal situação. Salienta, ainda, que algumas vezes, os conceitos utilizados pelo legislador no pressuposto da norma (na situação fática por ela descrita, isto é, no "motivo legal") ou na finalidade, são fluídos, imprecisos, vagos, indeterminados ou elásticos, como, v.g., "situação urgente", "notável saber", "estado de pobreza", "ordem pública" (MELLO, 2007, p. 16).

$\mathrm{O}$ autor assevera que entre tais conceitos existe uma "zona de certeza positiva" e uma "zona de certeza negativa":

De qualquer deles se pode dizer que compreendem uma zona de certeza positiva, dentro da qual ninguém duvidaria do cabimento da aplicação da palavra que os designa e uma zona de certeza negativa em que seria certo que por ela não estaria abrangida. As dúvidas só tem cabida no intervalo entre ambas. Isto significa que em inúmeros casos será induvidoso que uma situação é, exempli gratia, urgente, ou que seguramente não o é; que há um interesse público relevante ou que certamente não há; que dado cidadão tem reputação ilibada ou não a tem; que possui ou não possui notável saber; que determinado evento põe em risco a segurança pública, a moralidade pública, a tranquilidade pública ou, pelo contrário, que não as molesta.

Tais expressões, como se pode constatar, são dotadas de intrínseca subjetividade. Não é possível aferir, objetivamente, quais situações fáticas são abarcadas por seus significados, de tal sorte que competirá ao gestor da coisa pública, no exercício da atividade administrativa e sempre buscando o interesse da cole- 
tividade, interpretar se o caso concreto poderá se enquadrar na hipótese legal.

Mello (2007, p. 17) vai além e afirma que, vezes outras, ainda que haja descrição estritamente objetiva no comando da norma, é conferida certa margem de liberdade ao administrador no que se refere, isolada ou cumulativamente: a) a agir ou não agir; b) à escolha da ocasião adequada para fazê-lo; c) à forma jurídica através da qual veiculará o ato; ou d) à eleição da medida considerada idônea perante aquela situação fática, para satisfazer a finalidade legal.

Nessa conjectura, Di Pietro (2014, p. 221) aponta três situações em que, normalmente, essa discricionariedade existe. Primeitro, "quando a lei expressamente confere à Administração, como ocorre no caso da norma que permite a remoção ex officio do funcionário, a critério da Administração, para atender à conveniência do serviço".

Em segundo, "quando a lei é omissa, porque não lhe é possível prever todas as situações supervenientes ao momento de sua promulgação, hipótese em que a autoridade deverá decidir de acordo com princípios extraídos do ordenamento jurídico". (Id. Ibid.)

E, por fim, quando há a previsão legal de determinada competência, sem, contudo, se estabelecer "a conduta a ser adotada; exemplos dessa hipótese encontram-se em matéria de poder de polícia, em que é impossível à lei traçar todas as condutas possíveis, diante de lesão ou ameaça de lesão à vida, à segurança pública, à saúde". (Id. Ibid.)

No tocante aos requisitos do ato administrativo, a discricionariedade não pode recair sobre a competência, pois esta é sempre fixada pela lei.

Quanto à finalidade, somente poderá recair sobre o seu aspecto amplo - para se aferir se a finalidade é de ordem pública, moral, de segurança, etc. Em sentido estrito, existe sempre vinculação, pois para cada ato administrativo previsto pelo legislador, há uma finalidade específica que não deve ser contrariada.

No que se refere à forma, os atos são, a rigor, vinculados, salvo na hipótese em que o legislador prevê mais de uma forma possível destinada à prática do ato.

Infere-se, portanto, que a discricionariedade se concentra, precipuamente, sobre o motivo e conteúdo (objeto) do ato. Recairá sobre este quando a lei prever mais de um objeto possível para atingir o mesmo fim, como, por exemplo, quando determina a aplicação alternativa entre diferentes penalidades para coibir uma infração praticada por servidor. Recairá sobre aquele quando a lei não definir o exato motivo do ato ou, ainda, quando fizer uso dos chamados conceitos fluidos, já mencionados acima.

Juntamente com a noção de discricionariedade, está o conceito do chamado mérito administrativo, que se consubstancia na valoração dos motivos e na escolha do objeto do ato, feitas pela Administração incumbida de sua prática, 
quando autorizada a decidir sobre a conveniência, oportunidade e justiça do ato prestes a realizar (MEIRELLES, 2014, p. 171).

Mello (2007, p. 38) define o mérito administrativo como:

O campo de liberdade suposto na lei e que, efetivamente, venha a remanescer no caso concreto, para que a o administrador, seguindo critérios de conveniência e oportunidade, se decida entre duas ou mais soluções admissíveis perante ele, tendo em vista o exato atendimento da finalidade legal, dada a impossibilidade de ser objetivamente reconhecida qual delas seria a única adequada.

Em outras palavras, o mérito administrativo é o aspecto do ato relativo à conveniência e oportunidade; só existe, portanto, nos atos discricionários. Diante disso, pode-se afirmar que o ato vinculado é analisado apenas sob o aspecto da legalidade, ao passo que o ato discricionário deve ser analisado sob o aspecto da legalidade e do mérito: o primeiro refere-se à conformidade do ato com a lei e o segundo diz respeito à oportunidade e conveniência diante do interesse público a atingir (DI PIETRO, 2014, p. 226).

Muito importante a ressalva feita por Meirelles (2014, p. 185):

Insistimos mais uma vez, que ato discricionário não se confunde com ato arbitrário. Discrição e arbítrio são conceitos inteiramente diversos. Discrição é liberdade de ação dentro dos limites legais; arbítrio é ação contrária ou excedente da lei. Ato discricionário, portanto, quando permitido pelo Direito, é legal e válido; ato arbitrário é, sempre e sempre, ilegítimo e inválido.

Em sede conclusiva, Mello (2007, p. 32) ressalta que, não obstante a discricionariedade inserta no comando da norma, o Poder Público, ao deliberar sobre o mérito administrativo, deverá sempre adotar a melhor solução possível.

Explica-se:

Se a lei impõe conduta vinculada à Administração Pública, parece que sabe exatamente o comportamento único e ideal, segundo o qual atenderá, com perfeição, no caso concreto, o interesse público almejado.

Já nas situações em que há margem para se ponderar sobre a conveniência e oportunidade do ato, estando-se, evidentemente, diante de ato discricionário, infere-se que o legislador não obteve êxito em fixar, previamente, qual o comportamento administrativo capaz de assegurar, em qualquer caso, a única solução apta a atender, com perfeição, o interesse público que ensejou a criação da norma.

Ora, justamente por buscar o comportamento administrativo perfeito, 
idôneo e adequado ao caso concreto, e ante a multiplicidade de situações que poderão surgir no exercício da atividade administrativa, a lei confere à Administração - incumbida de analisar os casos concretos, com todas suas peculiaridades - a prerrogativa de sopesar as circunstâncias e dar satisfação à finalidade legal.

Logo, outra conclusão não resta senão a de que a existência da discricionariedade só admite a escolha da melhor solução, por parte do gestor da coisa pública, aos casos concretos. Não pode o Poder Público, assim, eleger qualquer das soluções, mas, sim, aferir e optar pela mais útil e oportuna à situação fática analisada, levando sempre em consideração que, em sede de Direito Administrativo, busca-se assegurar a coexistência pacífica das pessoas e atingir um estado de bem-estar social.

\section{Controle Judicial dos Atos Administrativos Discricionários}

Conforme já referido, a Administração Pública, no exercício de suas funções, deve atuar com legitimidade, isto é, em obediência às normas adequadas a cada ato e em conformidade com a finalidade e o interesse coletivo que pressupõe a sua realização. Tal exigência envolve tanto os atos vinculados como os discricionários, pois nestes últimos a conduta do administrador necessita ser legítima, segundo as opções permitidas em lei elevando-se em conta sempre a presteza na busca pelo bem comum (MEIRELLES, 2014, p. 753).

No ensinamento de Meirelles (2014, p. 753), controle "em tema de administração pública, é a faculdade de vigilância, orientação e correção que um Poder, órgão ou autoridade exerce sobre a conduta funcional de outro".

Ao desobedecer à lei, atuando em desconformidade com os princípios básicos da Administração, ou excedendo as regras de competência ou, ainda, desvinculando-se da finalidade do ato, o administrador eiva o ato de ilegitimidade e o expõe à anulação, realizada pela própria Administração ou pelo Poder Judiciário, quando provocado (MEIRELLES, 2014, p. 753).

O Brasil adotou o sistema da inafastabilidade da jurisdição, como se pode observar no artigo $5^{\circ}$, inciso XXXV, da Constituição Federal, que proíbe a lei de excluir da apreciação do Poder Judiciário lesão ou ameaça de direito mesmo que o autor da lesão seja o Poder Público.

A Constituição Federal de 1988 prevê ações próprias ao controle da Administração Pública, denominadas "remédios constitucionais", que constituem garantias dos direitos fundamentais. São eles: habeas corpus, habeas data, mandado de segurança, mandado de injunção, ação popular e ação civil pública.

No que se refere aos atos vinculados, não existe restrição do controle exercido pelo Poder Judiciário, uma vez que todos seus elementos são definidos em lei, competindo aos magistrados examinarem a conformidade do ato com a 
legislação e, sendo o caso, decretar sua nulidade.

Por outro lado, nos atos discricionários, embora o controle seja possível, deve respeitar a discricionariedade administrativa nos limites em que ela foi assegurada à Administração Pública pelo legislador. Conforme dito anteriormente, a rigor o Judiciário pode apreciar os aspectos da legalidade e verificar se a Administração não ultrapassou os limites da discricionariedade; neste último caso, pode o Judiciário invalidar o ato quando a autoridade administrativa ultrapassou o espaço livre deixado pela lei, caso em que invadiu o campo da legalidade (DI PIETRO, 2014, p. 229).

Nessa conjectura, assinala Mello (2014, p. 996-997):

Assim como ao Judiciário compete fulminar todo comportamento ilegítimo da Administração que apareça como frontal violação da ordem jurídica, compete-lhe, igualmente, fulminar qualquer comportamento administrativo que, a pretexto de exercer apreciação ou decisão discricionária, ultrapassar as fronteiras dela, isto é, desbordar dos limites de liberdade que lhe assistiam, violando, por tal modo, os ditames normativos que assinalam os confins da liberdade discricionário.

Ora, não deixa de ser exame de legitimidade e que poderá acarretar invalidação aquele exercido sobre ato supostamente discricionário, sempre que seja objetivamente demonstrável que a conduta adotada pela Administração Pública não foi a providência "ótima" almejada pelo legislador, pois, nesses casos, não terá ocorrido exercício de discrição administrativa, mas tão somente violação do Direito (MELLO, 2007, p. 48).

O Poder Judiciário, no exame de ato discricionário, deverá se valer do princípio da razoabilidade, uma vez que a valoração subjetiva, realizada pela Administração Pública ao praticar ato discricionário, necessita ser feita dentro do razoável, ou seja, em conformidade com aquilo que, para o senso comum, seria aceitável e adequado perante a lei (DI PIETRO, 2014, p. 230).

A doutrina vem desenvolvendo algumas teorias para fixar os limites ao exercício do poder discricionário, de maneira a ampliar a possibilidade de sua apreciação pelo Poder Judiciário.

A primeira delas é a teoria do desvio de poder.

Mello (2007, p. 57) traz conceito breve e adequado de desvio de poder:

Consiste, pois, no manejo de um plexo de poderes (competência) procedido de molde a atingir um resultado diverso daquele em vista do qual está outorgada a competência. O agente se evade do fim legal, extravia-se da finalidade cabível em face da lei. Em suma: falseia, deliberadamente ou não, com intuitos subalternos ou não, aquele seu 
dever de operar o estrito cumprimento do que a lei configurou como objetivo prezável e atingível por dada via jurídica.

Infere-se, dessa forma, que ocorre o desvio de poder quando o agente público utiliza-se do poder discricionário para atingir fim diferente daquele que a lei fixou. Logo, por via de consequência, poderá o Poder Judiciário anular o ato.

Como exemplo, imagine situação hipotética em que o agente público remove um servidor para outro setor com o objetivo de puni-lo por erro cometido no trabalho, justificando-se, para tanto, pelo "interesse da Administração", conceito fluído previsto na lei. Uma vez que a remoção não possui caráter punitivo, observa-se que o agente desviou-se do fim específico de interesse público previsto na legislação. Assim, não poderá ser acobertado pela discricionariedade do ato, pois seu comportamento consistiu em verdadeira violação de norma legal.

Conclui Mello (2007, p. 57):

Tratando-se, com se trata, de um comportamento que desgarra do fim legal, é, em suma, uma transgressão da lei. Por isso o controle jurisdicional do desvio de poder é um controle de estrita legalidade. E modo algum agride a margem de liberdade administrativa, isto é, a discrição que a lei haja conferido ao agente.

Existem duas hipóteses em que se verifica o desvio de poder. Na primeira, o agente busca uma finalidade alheia a qualquer interesse público, para alcançar um fim pessoal - que tanto pode ser de perseguição ou de favoritismo ou mesmo para assegurar qualquer interesse individual (MELLO, 2007, p. 59).

$\mathrm{Na}$ segunda, busca atender uma finalidade pública que não é a própria, específica, da competência utilizada. Valer-se-á, portanto, de uma competência inadequada, de direito, para atingir a finalidade almejada. Nessa hipótese, ainda que tenha atuado de boa-fé, acreditando que se valia da competência correta, incorrerá em desvio de poder, devendo o ato, em ambas as hipóteses, ser fulminado pelo Poder Judiciário (MELLO, 2007, p. 59).

Outra teoria é a dos motivos determinantes: quando a Administração indica os motivos que a levaram a praticar o ato, este somente será válido se os motivos forem verdadeiros. Assim, o Judiciário terá que examinar os pressupostos de fato e as provas da ocorrência do motivo (DI PIETRO, 2014, p. 229).

Nas palavras de Mello (2007, p. 86), "se inocorrem os motivos supostos na lei, falta à autoridade um requisito insuprimível para mobilizar poderes cuja disponibilidade está, de antemão, condicionada à presença do evento que lhes justifica o uso".

É de extremo relevo observar que não basta que determinado evento tenha ocorrido: este deve ser precisamente aquilo que a lei buscava. Deve haver, 
portanto, uma subsunção entre a situação que embasou a providência administrativa e aquela a que a lei previu, sob pena de invalidação do ato.

Exemplificativamente, cabe citar a existência de motivos insertos em expressões na legislação que autorizam à Administração a prática de determinadas medidas, como "perturbação da tranquilidade pública", "urgência", "comportamento indecoroso". Como já se discutiu no presente trabalho, esses conceitos vagos ou fluídos são eminentemente subjetivos.

Restará ao juiz verificar a plausabilidade da situação de fato que, aos olhos do administrador, ensejou a prática do ato. Se entender, orientado pelo princípio da razoabilidade, que o motivo atende àquilo que fora determinado pelo legislador, não poderá adentrar mais além no campo da discricionariedade administrativa.

Deve-se ressalvar sempre que a apreciação do Poder Judiciário é limitada, pois a indeterminação dos conceitos fluídos não permite a uma única interpretação do que é plausível e justo - seja na determinação do motivo ou da finalidade. Pode haver várias interpretações consideradas justas e abrangidas pela vontade do legislador, de tal sorte que o Poder Judiciário deve se ater, conforme dito anteriormente, sobre a razoabilidade ou irrazoabilidade da intelecção adotada.

É que, entre a zona de certeza positiva e a zona de certeza negativa do que pode ser abarcado por um conceito indeterminado previsto na legislação, existem inúmeras e inúmeras situações. Destarte, não pode o órgão julgador rechaçar a intelecção do órgão que exerça a atividade administrativa sob a única justificativa de que sua própria intelecção é a mais adequada. Somente poderá atacá-la diante de uma "abusiva dilatação do sentido da norma, uma desproporcional extensão do sentido extraível do conceito legal ante os fatos a que se quer aplicá-lo" (MELLO, 2007, p. 92).

Finalmente, outra teoria que vigora sobre o controle judicial dos atos administrativos discricionários é a do exame da causa do ato.

Sobre o assunto, leciona Mello (2007, p. 94):

Faltando explícita menção legal aos motivos propiciatórios de um ato, serão admissíveis apenas os que possam ser reputados implicitamente respaldados pela lei, por corresponderem a situações que demandaram a prática de um ato idôneo para atendimento da finalidade normativa. É de mister, pois, nestes casos, verificar se há relação de pertinência lógica, ou seja, de adequação à face de princípios encampados pelo Direito, entre a situação tomada como base para a prática do ato e a finalidade que a lei atribui à competência exercitada. É aqui que se propõe o tema do que chamaremos causa do ato administrativo. 
Com efeito, ainda que não haja expressa menção legal do motivo do ato, se o Poder Público embasa-se em determinados eventos ou situações e diante deles pratica ato desproporcional ao que era requerido, ainda que implicitamente, para atingir o fim legal, sendo ele considerado inapto, imprestável, inadequado ou excessivo, verifica-se que as causas em que se apoiou não justificam o comportamento adotado (MELLO, 2007, p. 95). Diante disso, plenamente cabível a intervenção do Judiciário, desde que provocado.

Cumpre mencionar, porque relevante, o posicionamento de Mello (2014, p. 993). acerca das hipóteses de controle judicial sobre atos discricionários supramencionadas.

A interpretação do sentido da lei, para pronúncia judicial, não agrava a discricionariedade, apenas the reconhece os confins; não penetra na esfera de liberdade administrativa, tão só lhe declara os contornos; não invade o mérito do ato nem se interna em avaliações inobjetiváveis, mas recolhe a significação possível em função do texto, do contexto e da ordenação normativa como um todo, aprofundando-se até o ponto em que pode extrair razoavelmente da lei um comando certo e inteligível.

O que se pretende demonstrar, portanto, é que a tendência que se observa na doutrina e jurisprudência modernas, de expandir o alcance da apreciação do Poder Judiciário, não implica em invasão do mérito administrativo e consequente violação à separação dos poderes; o que se procura é limitar a discricionariedade da Administração Pública e impedir eventuais arbitrariedades e lesões ao interesse da coletividade.

\section{Exposição e Análise de Precedentes do Supremo Tribunal Federal e do Superior Tribunal de Justiça}

Dirimida a discussão doutrinária sobre a possibilidade de intervenção do Poder Judiciário nos atos da Administração Pública, notadamente no mérito administrativo, cumpre abordar o entendimento dos Tribunais Superiores acerca do tema.

Em uma divisão meramente indicativa - que, por óbvio, não descarta outras possibilidades -, França (2011, p. 128) apresenta cinco situações em que o STF e o STJ se debruçam sobre o mérito administrativo:

(a) não se aceita, simplesmente, a sindicabilidade do mérito administrativo; (b) utiliza-se do controle do mérito administrativo, quando se trata de mero controle de legalidade; (c) faz-se um controle do mérito 
administrativo indireto, sem assumir frontalmente que o realiza, tentando preservar o máximo dos princípios constitucionais, por meio de um exercício de ponderação de valores envolvidos; (d) aceita-se o controle do mérito administrativo de forma regular e em casos excepcionais; (e) afasta-se o controle do mérito administrativo, em razão da inadequação do meio processual utilizado no exercício da pretensão jurisdicional.

Quanto à situação (a), compreende casos em que o Judiciário nega a interveniência ao mérito administrativo, sob a justificativa de que o controle judicial não se aplica sobre atos de conveniência e oportunidade da Administração Pública.

Nesse sentido já se posicionou o STF por inúmeras vezes, como se vê:

O Decreto 420/1992 estabeleceu alíquotas diferenciadas - incentivo fiscal - visando dar concreção ao preceito veiculado pelo art. $3^{\circ}$ da Constituição, ao objetivo da redução das desigualdades regionais e de desenvolvimento nacional. Autoriza-o o art. 151, I da Constituição. (...) A concessão do benefício da isenção fiscal é ato discricionário, fundado em juízo de conveniência e oportunidade do Poder Público, cujo controle é vedado ao Judiciário. (BRASIL, STF, 2007).

A Constituição, na parte final do art. 151, I, admite a 'concessão de incentivos fiscais destinados a promover o equilíbrio do desenvolvimento sócio-econômico entre as diferentes regiões do país'. A concessão de isenção é ato discricionário, por meio do qual o Poder Executivo, fundado em juízo de conveniência e oportunidade, implementa suas políticas fiscais e econômicas e, portanto, a análise de seu mérito escapa ao controle do Poder Judiciário. Precedentes: RE 149.659 e AI 138.344-AgR. (BRASIL, STF, 2003).

O STJ também já se manifestou dessa forma, conforme se observa nos seguintes precedentes:

1. Este Superior Tribunal de Justiça tem entendimento pacificado no sentido de que, nos casos de licenciamento ex officio de militar não estável, a bem da disciplina, não é necessária a instauração de processo administrativo, bastando a cientificação do militar para que exerça o seu direito defesa. 2. É inviável a incursão pelo Poder Judiciário sobre o mérito administrativo. 3. Recurso ordinário improvido. (BRASIL, STJ, 2009)

I. A atuação do Poder Judiciário no controle dos atos administrativos 
limita-se aos aspectos da legalidade e moralidade, obstaculizado o adentrar do âmbito do mérito administrativo, da sua conveniência e oportunidade. II. Se o Tribunal a quo, com base na análise do acervo probatório produzido nos autos, reconheceu que a remoção do servidor ocorreu como represália, com desvio de finalidade, infirmar tal entendimento ensejaria o reexame de provas, o que encontra óbice no verbete da Súmula $\mathrm{n}^{\mathrm{o}} 07$ deste Tribunal. Recurso não conhecido. (BRASIL, STJ, 2005)

Seguindo essa mesma linha de raciocínio, os Tribunais admitiram a intervenção no mérito administrativo quando se tratou de mero controle de legalidade - hipótese (b). Nessa situação, entendeu-se que não há violação ao princípio da separação dos poderes (separação de funções do Estado).

Seguem precedentes do STF:

2. Expulsão. Estrangeiro condenado por tráfico de entorpecentes. Decreto presidencial. Existência de causa legal. Conveniência e oportunidade. Ato discricionário do Presidente da República. Sujeição a controle jurisdicional exclusivo da legalidade e constitucionalidade. É discricionário do Presidente da República, que lhe avalia a conveniência e oportunidade, o ato de expulsão, o qual, devendo ter causa legal, só está sujeito a controle jurisdicional da legalidade e constitucionalidade. (BRASIL, STF, 2004)

Controle de legalidade dos atos administrativos pelo Poder Judiciário. Ausência de violação ao princípio da separação de poderes. Agravo Regimental ao qual se nega provimento. I - Decisão agravada que indeferiu o pedido de contracautela dianta da ausência de comprovação da alegada lesão à ordem e à economia públicas. II - O Supremo Tribunal Federal pacificou o entendimento de que não viola o princípio da separação dos poderes o exame, pelo Poder Judiciário, do ato administrativo tido por ilegal ou abusivo. Precedentes. III - A contratação administrativa para a mera alocação de mão de obra, inclusive para o desempenho de atividades finalísticas da administração pública, pode ser danosa ao interesse público, ferindo os comandos constitucionais inseridos no caput e no inciso II do art. 37. Risco de dano inverso. Precedente. (BRASIL, STF, 2015)

É esse também o entendimento do STJ, que entende que o princípio da razoabilidade e da proporcionalidade, fundados no devido processo legal, advêm da legalidade, de modo que tais aspectos podem ser analisados pelo Poder Judiciário no "exame estrito da legalidade": 
1. A jurisprudência do STJ admite, excepcionalmente, a concessão de efeito modificativo ao julgado em embargos de declaração. 2. É sabido que em tema de controle judicial dos atos administrativos, a razoabilidade, assim como a proporcionalidade, fundadas no devido processo legal, decorrem da legalidade, por isso que podem e devem ser analisadas pelo Poder Judiciário, quando provocado a fazê-lo. 3 . A pena de demissão deve ser revista pelo Poder Judiciário, quando desarrazoada e desproporcional ao fato apurado no PAD, o que ocorreu nos presentes autos. Precedentes do STJ. (BRASIL, STJ, 2009)

De mais a mais, merecem especial destaque os fundamentos utilizados pelo STJ no julgamento do RMS 20.271/GO:

3. Os atos discricionários legitimam espaço de liberdade para o administrador, insindicável pelo Poder Judiciário, porquanto nessas hipóteses interditada a intervenção no mérito do ato administrativo. 4. É cediço na doutrina que: '[...] Já se tem reiteradamente observado, com inteira procedência, que não há ato propriamente discricionário, mas apenas discricionariedade por ocasião da prática de certos atos. Isto porque nenhum ato é totalmente discricionário, dado que, conforme afirma a doutrina prevalente, será sempre vinculado com relação ao fim e à competência, pelo menos. Com efeito, a lei sempre indica, de modo objetivo, quem é competente com relação à prática do ato - e aí haveria inevitavelmente vinculação também com respeito a este aspecto. [...] Em suma, discricionariedade é liberdade dentro da lei, nos limites da norma legal, e pode ser definida como: 'A margem de liberdade conferida pela lei ao administrador a fim de que este cumpra o dever de integrar com sua vontade ou juízo a norma jurídica, diante do caso concreto, segundo critérios subjetivos próprios, a fim de dar satisfação aos objetivos consagrados no sistema legal'. [...] Nada há de surpreendente, então, em que o controle judicial dos atos administrativos, ainda que praticados em nome de alguma discrição, se estenda necessária e insuperavelmente à investigação do motivos, da finalidade e da causa do ato. Nenhum empeço existe a tal proceder, pois é meio - e, de resto fundamental - pelo qual se pode garantir o atendimento da lei, a afirmação do direito. [...] Assim como ao Judiciário compete fulminar todo o comportamento ilegítimo da Administração que apareça como frontal violação da ordem jurídica, compete-lhe, igualmente, fulminar qualquer comportamento administrativo que, a pretexto de exercer apreciação ou decisão discricionária, ultrapassar as fronteiras dela, isto é, desbordar dos limites de liberdade que lhe assistiam, violando, por tal modo, os ditames normativos que assinalam os confins da liberdade discricionária (MELLO, 2014, p. 395; 836-837). 5. Deveras, contexto fático encartado nos autos denota 
a ausência de direito líquido e certo do impetrante, ora recorrente, a uma: porque o juiz, ora impetrado, no exercício de competência discricionária, nenhuma ilegalidade praticou ao nomear interventor, imparcial para administração do cartório em comento, a fim de resguardar o bom andamento das investigações acerca do oficial titular; a duas: porque a impetrante, ora recorrente, é casada com o oficial titular, então afastado por supostas irregularidades cartorárias e seria difícil a mesma colaborar na devassa a ser realizada na serventia, em especial quanto as provas apresentadas são contrárias ao seu esposo e filho, escrevente no referido cartório e acusado de falsidade no reconhecimento de firma. 6. In casu, o Tribunal a quo decidiu em consonância com o preceito legal (art. 36, § $1^{\circ}$, da Lei 8.935/94), (...) o magistrado agiu com discricionariedade, entre várias possibilidades de solução, acolheu a que melhor correspondia, no caso concreto, o desejo da lei [...]. (BRASIL, STJ, 2009)

No tocante à situação (c), o Poder Judiciário intervém no juízo de conveniência e oportunidade da Administração Pública, mas de maneira indireta isto é, sem assumir adentrar no mérito administrativo -, motivado pela preservação dos princípios máximos constitucionais.

Nessa conjectura de idéias, a Suprema Corte assim se posicionou:

A exclusão de policial militar, mesmo que não estável, não prescinde da instauração de procedimento administrativo em que the sejam asseguradas as garantias do contraditório e da ampla defesa. Não viola o princípio da separação dos Poderes a anulação de todo ato administrativo que fere as garantias constitucionais do contraditório e da ampla defesa. (BRASIL, STF, 2005)

O STF igualmente adotou essa hipótese de controle sobre assunto de fundamental relevância: a (não) realização de políticas públicas por parte dos Poderes Legislativo e Executivo. De acordo com o ministro Celso de Mello, é possível que o Judiciário determine, em caso de omissão dos órgãos competentes, a efetivação de políticas públicas definidas na Carta Magna, de modo a assegurar a fruição de direitos fundamentais e sociais. Leia-se trecho da decisão proferida em agravo no RE 410.715/SP:

A educação infantil, por qualificar-se como direito fundamental de toda criança, não se expõe, em seu processo de concretização, a avaliações meramente discricionárias da Administração Pública, nem se subordina a razões de puro pragmatismo governamental. Os Municípios - que atuarão, prioritariamente, no ensino fundamental e na educação infantil (art. $211, \S 2^{\circ}$, da $\mathrm{CF}$ ) - não poderão demitir-se 
do mandato constitucional, juridicamente vinculante, que lhes foi outorgado pelo art. 208, IV, da Lei Fundamental da República [decisão anterior a EC 53/2006], e que representa fator de limitação da discricionariedade político-administrativa dos entes municipais, cujas opções, tratando-se do atendimento das crianças em creche (art. 208, IV, da CF) [decisão anterior à EC 53/2006], não podem ser exercidas de modo a comprometer, com apoio em juízo de simples conveniência ou de mera oportunidade, a eficácia desse direito básico de índole social. Embora resida, primariamente, nos Poderes Legislativos e Executivo, a prerrogativa de formular e executar políticas públicas, revela-se possível, no entanto, ao Poder Judiciário, determinar, ainda que em bases excepcionais, especialmente nas hipóteses de políticas públicas definidas pela própria Constituição, sejam estas implementadas pelos órgãos estatais inadimplentes, cuja omissão - por importar em descumprimento dos encargos políticos que sobre eles incidem em caráter mandatório - mostra-se apta a comprometer a eficácia e a integridade de direitos sociais e culturais impregnados de estatura constitucional. (BRASIL, STF, 2005)

Sobre a situação (d), realiza-se controle do mérito administrativo como regular dever do Judiciário ou em casos excepcionais. À título exemplificativo, colaciona-se a seguir decisums do Pretório Excelso:

2. A autoridade administrativa está autorizada a praticar atos discricionários apenas quando norma jurídica válida expressamente a ela atribuir essa livre atuação. Os atos administrativos que envolvem a aplicação de "conceitos indeterminados" estão sujeitos ao exame e controle do Poder Judiciário. O controle jurisdicional pode e deve incidir sobre os elementos do ato, à luz dos princípios que regem a atuação da Administração. [...] Recurso ordinário provido. (BRASIL, STF, 2004)

I - Cabe ao Poder Judiciário verificar a regularidade dos atos normativos e de administração do Poder Público em relação às causas, aos motivos e à finalidade que os ensejam. II - Pelo princípio da proporcionalidade, há que ser guardada correlação entre o número de cargos efetivos e em comissão, de maneira que exista estrutura para atuação do Poder Legislativo local. (BRASIL, STF, 2007)

\section{E, por sua vez, o STJ:}

1. Nos termos do art. $5^{\circ}, \mathrm{XXXV}$, da Constituição Federal, 'a lei não excluirá da apreciação do Poder Judiciário lesão ou ameaça a direito. Assim, o controle judicial dos atos administrativos se mostra intima- 
mente atrelado à existência do Estado Democrático de Direito, no qual, em regra, será possível aferir a legalidade e regularidade do ato administrativo. Precedente. 2. O Poder Judiciário dever ser provocado pelo administrado para que exerça o controle judicial de eventual ato administrativo, sendo certo que essa provocação, em face do Princípio da Segurança Jurídica, pilar do Estado de Direito, deverá ocorrer dentro de um prazo prescricional legalmente previsto (...) 5. Recurso especial parcialmente conhecido e, nessa parte, provido. (BRASIL, STJ, 2006)

Por fim, quanto à situação (e), é afastado o controle do mérito administrativo em razão do inadequado meio processual utilizado pelo administrado:

1. É legítima a verificação, pelo Poder Judiciário, de regularidade do ato discricionário quanto às suas causas, motivos e finalidade. 2. A hipótese dos autos impõe o reexame de fatos e provas. Inviabilidade do recurso extraordinário. Súmula 279 do STF. Agravos regimentais aos quais se nega provimento. (BRASIL, STJ, 2008)

Em sede de mandado de segurança é vedado ao Judiciário promover dilação probatória ou incursão no mérito administrativo. Precedentes. 3. Segurança denegada. (BRASIL, STJ, 2004)

Da análise dos precedentes transcritos, conclui-se que o controle judicial do ato administrativo é imprescindível quando o Poder Público age em desconformidade ao direito considerado como um sistema harmônico. Não há que se falar em violação à separação dos Poderes, uma vez que a intervenção do Judiciário se dá apenas para corrigir vícios de legalidade da Administração Pública, ou quando esta adota critérios e conceitos desproporcionais, desarrazoados ou que não atendam à finalidade pública e os motivos pensados pelo legislador, de maneira a prejudicar a persecução pelo bem-estar social.

\section{Considerações Finais}

Ao longo deste trabalho, foram feitas considerações sobre os atos praticados pela Administração Pública na busca pela satisfação do interesse da coletividade, com especial destaque aos atos discricionários, bem como à hipótese de controle jurisdicional destes.

Foram abordados, com base no posicionamento de importantes juristas brasileiros e, ao final, no entendimento dos Tribunais, a diferenciação dos atos vinculados e discricionários e o controle judicial exercido sobre eles, ressaltando-se os limites da liberdade concedida pela lei à Administração na formulação 
do chamado mérito administrativo.

Verificou-se que, no campo da discricionariedade, o administrador deve se utilizar da hermenêutica jurídica a fim de emitir um juízo de conveniência e oportunidade para a prática do ato, sobretudo na subsunção de fatos concretos aos conceitos indeterminados propositalmente deixados pelo legislador. Desse modo, pode-se afirmar que sua atuação, ainda que discricionária, se limita aos princípios constitucionais, ao objetivo das leis e, especialmente, à supremacia do interesse público.

Amparado pelo princípio da inafastabilidade da jurisdição, o Poder Judiciário poderá, desde que provocado, analisar os aspectos legais dos atos discricionários. Tal análise não se restringe, como inicialmente foi sustentado pela doutrina e jurisprudência brasileiras, aos seus requisitos e pressupostos. Compreende, de forma precípua, a verificação de inconformidade com os princípios constitucionais da legalidade, da proporcionalidade, da razoabilidade, da moralidade, dentre outros, que poderá culminar na invalidação do ato.

A possibilidade de controle jurisdicional nesses termos não implica em deixar a Administração desprovida de qualquer poder de escolha, de maneira a inviabilizar seu funcionamento. Ao revés, pretende-se que ela utilize a liberdade conferida pelo legislador em determinados casos para adotar as melhores soluções entre aquelas possíveis, isto é, escolhas aptas a atingirem uma finalidade social e que não sejam imorais, desproporcionais ou motivadas por interesses privados.

É que a valoração subjetiva, realizada pela Administração Pública ao praticar ato discricionário, necessita ser feita dentro do razoável, isto é, de acordo com aquilo que, para o senso comum, seria adequado perante a lei. Se assim não for, caberá ao Judiciário intervir, invalidando o ato administrativo que não se coaduna com seu fim legal (teoria do desvio de poder), que foi praticado com base em motivo diverso do indicado (teoria dos motivos determinantes) ou cujas causas em que se apoiou não justificam o comportamento adotado (teoria do exame das causas).

A análise da jurisprudência brasileira, embora vacilante, demonstra que os órgãos julgadores podem efetuar o controle de ato administrativo discricionário, motivados pela inafastabilidade da tutela jurisdicional. Ao exercerem tal controle, não oferecem risco à separação dos Poderes, pois se limitam à invalidação de ato considerado ilegal, irrazoável ou desproporcional, por todos os motivos já mencionados.

Em sede conclusiva, observa-se, hodiernamente, que a discricionariedade administrativa vem sofrendo restrições perante a amplitude do controle judicial. Não se busca, entretanto, que o Judiciário intervenha nos atos da Administração Pública de forma ilimitada ou usurpatória, substituindo a figura do 
administrador. O que se pretende é que os órgãos jurisdicionais verifiquem se os gestores da coisa pública atuam em conformidade com o ordenamento jurídico, de forma a garantir o fiel cumprimento da Constituição Federal.

\section{Referências}

ARAÚJO, E. N. de. Curso de Direito Administrativo. 4. ed. São Paulo: Saraiva, 2009.

BRASIL. Constituição (1988). Constituição da República Federativa do Brasil: promulgada em 5 de outubro de 1988. 7. ed. Barueri: Manole, 2015.

. Lei 10.406, de 10 de janeiro de 2002. Institui o Código Civil. Disponível em http://www.planalto.gov.br/ccivil_03/leis/2002/110406.htm. Acesso em 20 mar. 2016.

. Superior Tribunal de Justiça. Embargos de Declaração no Mandado de Segurança 9.526/DF. Rel. min. Celso Limong, 24 jun. 2009.

. Superior Tribunal de Justiça. Recurso Especial 616771/CE. Rel. min. Felix Fischer, 18 mai. 2005.

. Superior Tribunal de Justiça. Mandado de Segurança 8.584/DF. Rel. min. Hélio Quaglia Barbosa, 24 ago. 2004.

. Superior Tribunal de Justiça. Recurso no Mandado de Segurança 16.946/PE. Rel. min. Maria Thereza de Assis Moura, 28 abr. 2009.

. Superior Tribunal de Justiça. Recurso no Mandado de Segurança 19.210/RS. Rel. min. Felix Fischer, 10 abr. 2006.

. Superior Tribunal de Justiça. Recurso no Mandado de Segurança 20.271/GO. Rel. min. Luiz Fux, 26 mai. 2009.

. Supremo Tribunal Federal. Agravo no Recurso Especial 365.368/SC. Rel. min. Ricardo Lewandowski, 22 mai. 2007.

. Supremo Tribunal Federal. Agravo no Recurso Especial 410.715/SP. Rel. min. Celso de Mello, 22 nov. 2005. . Supremo Tribunal Federal. Agravo no Recurso Especial 505.439/MA. 
Rel. min. Eros Grau, 12 ago. 2008.

. Supremo Tribunal Federal. Agravo Regimental na Suspensão Liminar 885/RJ. Rel. min. Ricardo Lewandowski, 25 nov. 2015.

. Supremo Tribunal Federal. Agravo de Instrumento 509.213/AL. Rel. min. Carlos Britto, 9 ago. 2005.

. Supremo Tribunal Federal. Agravo de Instrumento 630.997-AgR. Rel. min. Eros Grau, 24 abr. 2007.

. Supremo Tribunal Federal. Habeas Corpus 82.893/SP. Rel. min. Cezar Peluso, 17 dez. 2004.

. Supremo Tribunal Federal. Recurso Especial 344.331. Rel. min. Ellen Gracie, 11 fev. 2003.

. Supremo Tribunal Federal. Recurso em Mandado de Segurança 24.699/DF. Rel. min. Eros Grau, 30 nov. 2004.

. Supremo Tribunal Federal. Súmula n. 346, 13 dez. 1963.

. Supremo Tribunal Federal. Súmula n. 473, 3 dez. 1969.

CARVALHO, K. G. Direito Constitucional. 15. ed. Belo Horizonte: Del Rey, 2009.

DI PIETRO, M. S. Z. Direito Administrativo. 27. ed. São Paulo: Atlas, 2014.

FRANÇA, P. G. O Controle da Administração Pública. 3. ed. São Paulo: Revista dos Tribunais, 2011

JUSTEN FILHO, M. Curso de direito administrativo. 6. ed. Belo Horizonte: Fórum, 2010.

MEIRELLES, H. L. Direito Administrativo Brasileiro. 40. ed. São Paulo: Malheiros, 2014.

MELLO, C. A. B. de. Curso de Direito Administrativo. 31. ed. São Paulo: Malheiros, 2014. 
. Discricionariedade e Controle Jurisdicional. 2. ed. São Paulo: Malheiros, 2007.

MORAES, A. de. Direito Constitucional. 20. ed. São Paulo: Atlas, 2006.

PEGORARO, L. N. Controle Jurisdicional dos Atos Administrativos Discricionários. Campinas: Servanda, 2010.

SPLITZCOVSKY, C. Direito Administrativo. 14. ed. São Paulo: Método, 2013.

\title{
JUDICIAL CONTROL OF ADMINISTRATIVE DISCRETION, FOCUSING ON THE SUPREME FEDERAL COURT AND THE SUPERIOR COURT OF JUSTICE JURISPRUDENCE
}

\begin{abstract}
This article aims to demonstrate the possibility of judicial control in administrative discretion, based on the Constitution. For a long time, legal doctrine and jurisprudence supported that the Judiciary Branch review of discretionary action should be restricted to legal aspects, without entering in the administrative merit. However, nowadays theories were developed, and applied in some cases by the Supreme Federal Court and the Superior Court of Justice, that limit administrative discretion and enlarge the possibilities of judicial control in order to avoid State arbitrariness and satisfy community interests.

KEYWORDS: Administrative action; Administrative discretion; Judicial control; Public Administration; Superior Court of Justice; Supreme Federal Court.

\section{CONTROL JUDICIAL DE DISCRECIONALIDAD ADMINISTRATIVA, CON ENFOQUE EN LA JURISPRUDENCIA DEL SUPREMO TRIBUNAL FEDERAL Y DEL SUPERIOR TRIBUNAL DE JUSTICIA}

RESUMEN: En este artículo se ha buscado demostrar la posibilidad de control jurisdiccional de la discrecionalidad administrativa, a la luz de la Constitución Federal. Durante mucho tiempo, la doctrina y la jurisprudencia sostuvieron que la intervención del Poder Judiciario sobre los actos discrecionales debería restringirse a los aspectos de legalidad, sin entrar en el examen del mérito administrativo. Sin embargo, se crearon las teorías modernas, aplicadas en algunos casos por el Supremo Tribunal Federal y por el Superior Tribunal de Justicia, que limitan la discrecionalidad administrativa y amplían las hipótesis de control judicial, con el fin de evitar arbitrariedades estatales y satisfacer los intereses de la colectividad. 
114 Controle judicial da discricionariedade...

PALABRAS CLAVE: Acto administrativo; Administración Pública; Control jurisdiccional; Discrecionalidad administrativa; Superior Tribunal de Justicia; Supremo Tribunal Federal. 